\title{
The Role of Critical Reading to Promote Students' Critical Thinking and Reading Comprehension
}

\author{
Syaadiah Arifin iD \\ Muhammadiyah Prof. Dr. Hamka University, Jakarta, Indonesia \\ *Corresponding author: syaadiah.arifin@uhamka.ac.id
}

\begin{abstract}
Developing students' critical thinking and reading comprehension is crucial, particularly for those in colleges, because they need to read numerous scientific journals and textbooks written in English. Therefore, students need to employ critical reading strategies to raise their critical thinking skills for a successful academic life. However, current studies have shown a lack of critical thinking strategies among Indonesian students, thereby leading to various academic problems, particularly the inability to comprehend English. Therefore, this research aims to explore critical reading's role to support students' critical thinking and reading comprehension skills when reading a text. This is a qualitative research with the purposive random technique used to obtain data from seven (7) EFL non-English major undergraduate students in their 2nd semester through three (3) short argumentative texts, a semi-structured interview, and students' answers in written forms. The results showed that students developed their critical thinking skills and improved their reading comprehension in varying degrees by exposure to numerous tasks.
\end{abstract}

Keywords: Critical Reading, Critical Thinking, Reading Comprehension

$\begin{array}{ll}\text { History: } & \text { Publisher: Undiksha Press } \\ \text { Received : 20 August } 2020 & \text { Licensed: This work is licensed under } \\ \text { Revised : } 11 \text { September } 2020 & \text { acreative Commons Attribution 3.0 License } \\ \text { Accepted : 26 September } 2020 & \text { Published : } 7 \text { October } 2020\end{array}$

\section{Introduction}

Reading is an essential language skill for students to succeed academically (Brown, 2000; Dorkchandra, 2013). Therefore, students must read and comprehend the text written in various books to understand the subject matters. According to Grabe \& Stoller (2013), reading comprehension requires the ability to properly understand and interpret the material's information. It involves many aspects such as vocabulary mastery, the relationships between words and concepts, managing ideas, identifying the writers' purposes, evaluating the context, and achieving decisions (Chou, 2011).

Critical reading needs to be introduced in formal education, particularly for university students. However, the accessible information expanded by reading sources, such as newspapers, magazines, or internet-based materials, is not always truthful. Therefore, critical reading skills enable students to acquire the needed meaning from different sources of information. Pardede (2007) stated that critical reading is basically a thinking and reading process that requires adequate understanding.

Teachers need to ensure students are taught how to become critical thinkers when teaching critical reading skills (Kadir \& Ismail, 2014). Critical readers tend to react towards what is being read due to their ability to comprehend beyond the content of the book 
critically (Din, 2020). Therefore, students' critical reading and thinking are indispensable in comprehending the content of a text (Kurland, 2000).

Readers can grow their critical thinking through different reading processes, along with interpretation, inference, and text-based insights. However, the data obtained from previous research indicated that Indonesian college students still lack reading literacy for several reasons, such as laziness, insufficient time, poor reading habit, lack of vocabulary and background knowledge, and the use of ineffective reading strategies (Velayati, Muslem, Fitriani, \& Samad, 2017; Wijayanti, 2020). Therefore, this current study explored critical reading's role to foster the critical thinking and reading comprehension of Indonesian undergraduate students majoring in Social and Political Sciences. This is because these students generally struggled to understand English texts.

Despite the importance of critical thinking in any educational field, it has brought about different conceptions and perspectives amongst numerous researchers (Ilyas, 2018; Reed, 1998). Moore (2013) stated that this term is the most elusive notion because it embraces a broad feature. Critical thinking has varying meanings to people in different contexts and cultures because it is not a simple concept to be defined (Halvorsen, 2005). However, most of the definitions have comparable values.

Books on critical thinking possess distinctive definitions with the model initially developed by Bloom (1956). Bloom's Taxonomy has been a well-known theory and considered a representative of a critical thinking theory's educational standpoint. Bloom (1956) defined critical thinking as the capability to achieve knowledge by investigating ideas regarding the subsequent six levels, namely, knowledge, comprehension, application, analysis, synthesis, and evaluation. Knowledge and comprehension are categorized as lowrank thinking skills, while the remaining levels belong to the higher stage. In Bloom's revised version (Anderson, Krathwohl, \& Bloom, 2001), there are six hierarchies in this revised version, namely remember, understand, apply, analyze, evaluate, and create. Critical thinking pedagogy consults Bloom's theory, thereby giving students a chance to practice at some lower levels before they proceed to higher levels. Meanwhile, Grigg et al. (1998) reported that critical thinking is a process of evaluating evidence with some claims while determining whether conclusions are logically derived from evidence and alternatives. Grigg also defined critical thinkers as people with questionable attitudes, openminded, ambiguous, and tolerating. Moreover, Paul \& Elder (2007b) stated that critical thinking is the ability to evaluate and analyze thinking to increase knowledge.

Therefore, from the above definitions, scholars believe that critical thinking is a multifaceted process. This means that readers need to go through some stages to analyze, evaluate, and understand academic materials critically. Therefore, they need to use their higher-order thinking skills proposed by Bloom's revised taxonomy, for analysis and evaluation (Anderson et al., 2001).

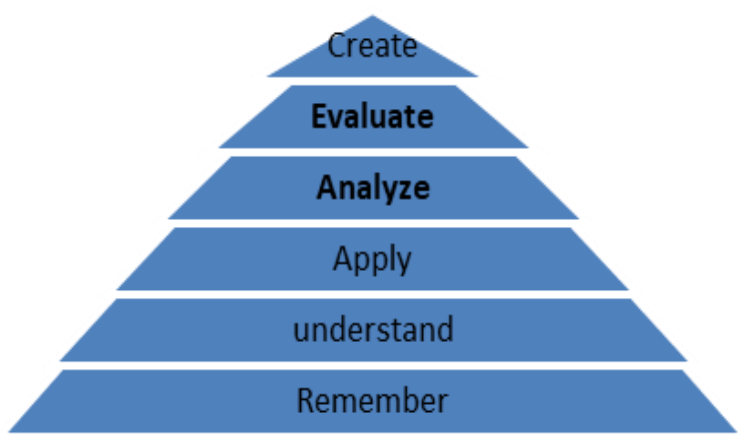

Figure 1. Revised Bloom Taxonomy 
There are various ways to develop students' critical thinking skills, such as through journal writing (Sinaga \& Feranie, 2017; Stanton \& Stanton, 2017) and critical reading (Fadhillah, 2017; Femilia, 2018; Karimi \& Veisi, 2016; McDonald, 2004). Karim \& Veisi (2016) researched 50 college students in Iran to assess the effect of teaching critical thinking skills on Iranian students. During the research, students were split into experimental and control groups. The experimental group was introduced to critical thinking skills, while the control group was taught with the traditional methods. The result showed that teaching critical thinking skills significantly affect students' reading comprehension abilities.

Furthermore, Femila (2018) carried out a study in East Java universities to determine the strategies used by good critical readers. The sample data comprised three students with the ability to read and comprehend. These three students applied varied critical reading strategies, using a sequence that formed an interactive reading model.

Critical reading enables younger students to cultivate critical thinking. Fadhillah (2017) researched to determine the critical thinking skills of Junior high schools in West Java in reading narrative texts using thirty-five eighth grade students. The study applied the mixed methodology, with data obtained from pre-test and post-test. The result showed that 18 out of 35 students made significant improvements in their critical thinking skills, proving that critical reading strategies help students think critically.

Commeyras (1990) stated that critical thinking is directly related to one's comprehension, written evidence, and background knowledge because reading offers a basis for ideas and activates many responses. Kurland (2000) also defined critical reading as an analytic activity involving readers' to analyze, interpret, evaluate, and comprehend reading materials. Therefore, readers need to analyze and evaluate their reading text before synthesizing their belief or thought in order to read critically. They also need to apply their critical thinking skills to monitor their understanding of the text, while connecting their background on what they read (Kurland, 2000). During this process, when readers perceive the assertion delivered in the text is absurd or careless, they tend to read the text more thoroughly and test their understanding of the knowledge to interpret, evaluate, and decide their alternative responses (Paul \& Elder, 2007a).

Bloom's taxonomy has been widely used to determine one's critical thinking skills (Shaarawy, 2014; Threlfall, 2014). Nevertheless, this research adopted a Critical Thinking Scoring Scheme created by Leist et al. (2012) for critical reading due to its appropriateness for the study's objective in determining critical reading's role to foster thinking and reading comprehension. Moreover, this study also adapted Xu's (2011) a five-step model to promote critical thinking in teaching reading. Therefore, this research aims to explore critical reading's role to support students' critical thinking and reading comprehension skills when reading a text.

\section{Materials and Methods}

The research is a case study of the techniques used by lecturers to introduce critical reading to students. The research, which was carried out from May to June 2020, comprises of 7 (seven) undergraduate students in the 2019/ 2020 academic year majoring in Social and Political Sciences whose English were still at the intermediate level.

A total of 7 students were purposively selected from 25 students for in-depth observation. The selected students were taught by the researcher in the first semester, therefore, they were already introduced to critical reading and thinking, even though it was not comprehensive. Another reason that led to the use of limited participants was that the research result acts as a reference to teach reading for the upcoming semesters, therefore, an in-depth observation was essential in order to achieve real information. 
The selected participants had a different level of English knowledge, with three (P5, P6. And P7), two (P3, and P4), and two (P1, and P2) students in the poor, moderate, and high categories based on their performances in semester one and two (semester 2 was not over yet at that time).

This is a qualitative research with data obtained from interview answers of seven (7) undergraduates majoring in Social and Political Sciences. The data were discussed, analyzed, and evaluated by two raters using the rubric method adapted from Leist et al. (2012). Furthermore, the semi-structured interview was used to triangulate the data gathered from the students' answers. This interview was also intended to discover their opinion on critical reading, thereby fostering their critical thinking and comprehension abilities.

Students' answers were analyzed in the second meeting, which indicated and noted that they encountered some difficulties, such as lack of English mastery, writing a conclusion, identifying implied meaning, and expressing an opinion. In this session, students' problematic parts and the inability to practice writing conclusions were analyzed. Some grammatical points, such as tenses, prepositions, and sentences, which previously taught, were also reviewed. The discussion and practice session is very important to improve students' critical thinking and comprehension.

The procedures of collecting data for the third to the eight meetings were the same as those in the first and second meetings. Each topic was followed by six (6) questions, which the students expected to answer individually.

The lecturers were assisted by their colleagues to rate the students' answers based on their critical thinking components when reading using the rubric process. Each point was elaborated in the rubric of Critical Thinking for Critical Reading, as shown in Table 1.

Paul and Elder's (2007b) framework applies a particular method of analysis and evaluation to provide students instructions on ways to increase their critical thinking skills. They also propose some Universal Intellectual Standards, such as clarity, accuracy, relevance, logicalness, breadth, precision, significance, Completeness, fairness, and depth. These standards need to be applied by ensuring consistency, and they need to be clearly instructed to understand the standards. Therefore, the ultimate aim is to infuse these principles into students' thoughts by becoming part of their inner speech and leading them to a better purpose. These standards have to be applied to the element of thought, namely Purposes, Questions, Points of view, Information, Inferences, Concepts, Implications, and Assumptions.

Leist et al. (2012) adopted 6 Universal Intellectual Standards created by Paul \& Elder (2007b) with the criteria and points shown I Table 1. The scoring system is concentrated on a chart form with four elements, namely (a) assignment characterization (reading prompt), (b) a range supporting degrees of accomplishment, (c) preferred skill types or dimensions, as well as (d) performance level categories. In this current study, the scoring system of Critical thinking and reading are shown in table 1 was used to assess the student's written responses.

Table 1. The rubric of Critical Thinking for Critical Reading

\begin{tabular}{lllll}
\hline \multicolumn{1}{c}{$\begin{array}{c}\text { Standard \& } \\
\text { Elements }\end{array}$} & \multicolumn{1}{c}{$\mathbf{1}$} & \multicolumn{2}{c}{$\mathbf{2}$} & \multicolumn{1}{c}{$\mathbf{3}$} \\
\hline $\begin{array}{l}\text { ACCURACY: } \\
\text { Recognizing the } \\
\text { main purpose(s) }\end{array}$ & $\begin{array}{l}\text { Highly inaccurate } \\
\text { with wrong or no } \\
\text { objective } \\
\text { mentioned }\end{array}$ & $\begin{array}{l}\text { Low accuracy } \\
\text { The purpose } \\
\text { mentioned } \\
\text { inaccurately }\end{array}$ & $\begin{array}{l}\text { Some accuracy } \\
\text { with the objective but } \\
\text { subtle inaccuracy }\end{array}$ & $\begin{array}{l}\text { Complete } \\
\text { accuracy and } \\
\text { specific intent }\end{array}$ \\
\hline $\begin{array}{l}\text { CLARITY: } \\
\text { understands }\end{array}$ & $\begin{array}{l}\text { Without the use of } \\
\text { data, fact or }\end{array}$ & $\begin{array}{l}\text { Improper or } \\
\text { minimum use of }\end{array}$ & $\begin{array}{l}\text { minimal use of reading } \\
\text { facts, information, or }\end{array}$ & $\begin{array}{l}\text { Frequent correct } \\
\text { use of the facts, }\end{array}$ \\
\hline
\end{tabular}




\begin{tabular}{|c|c|c|c|c|}
\hline $\begin{array}{l}\text { Facts, data } \\
\text { or examples } \\
\text { supported }\end{array}$ & readable details & $\begin{array}{l}\text { the facts, data, or } \\
\text { examples from } \\
\text { the reading }\end{array}$ & examples & $\begin{array}{l}\text { data, or } \\
\text { examples from } \\
\text { the reading }\end{array}$ \\
\hline $\begin{array}{l}\text { PRECISION: } \\
\text { Categorizing and } \\
\text { using the content, } \\
\text { and certain } \\
\text { vocabulary }\end{array}$ & $\begin{array}{l}\text { Includes no } \\
\text { content specific } \\
\text { vocabulary }\end{array}$ & $\begin{array}{l}\text { Low precision, } \\
\text { an attempt to use } \\
\text { the content- } \\
\text { specific } \\
\text { vocabulary, but } \\
\text { uses incorrectly } \\
\text { or minimally }\end{array}$ & $\begin{array}{l}\text { Some precision, does } \\
\text { incorporate content- } \\
\text { specific vocabulary, } \\
\text { may paraphrase } \\
\text { correctly }\end{array}$ & $\begin{array}{l}\text { Complete } \\
\text { precision with } \\
\text { frequent use of } \\
\text { content-specific } \\
\text { vocabulary, may } \\
\text { often paraphrase } \\
\text { correctly }\end{array}$ \\
\hline $\begin{array}{l}\text { DEPTH: } \\
\text { Demonstrating } \\
\text { complexity of } \\
\text { understanding }\end{array}$ & $\begin{array}{l}\text { No understanding } \\
\text { of the connections } \\
\text { among purpose, } \\
\text { concepts, and/or } \\
\text { support in the } \\
\text { reading }\end{array}$ & $\begin{array}{l}\text { Limited } \\
\text { comprehension } \\
\text { or relations in } \\
\text { reading purposes, } \\
\text { definitions }\end{array}$ & $\begin{array}{l}\text { Mainly understands th } \\
\text { e links between } \\
\text { intention, concepts and } \\
\text { /or reading help }\end{array}$ & $\begin{array}{l}\text { Complex } \\
\text { understanding } \\
\text { between } \\
\text { intent, concepts } \\
\text { and help in readi } \\
\text { ng the text }\end{array}$ \\
\hline $\begin{array}{l}\text { RELEVENCE: } \\
\text { Identifying/generati } \\
\text { ng conclusion and } \\
\text { adding personal } \\
\text { opinion based on } \\
\text { content }\end{array}$ & $\begin{array}{l}\text { No relevance or } \\
\text { conclusions stated }\end{array}$ & $\begin{array}{l}\text { Low relevance, } \\
\text { with basic } \\
\text { conclusions } \\
\text { stated }\end{array}$ & $\begin{array}{l}\text { Some relevance with } \\
\text { basic conclusions, but } \\
\text { does not personally } \\
\text { connect to the } \\
\text { concepts. }\end{array}$ & $\begin{array}{l}\text { Total relevance, } \\
\text { describes some } \\
\text { assumptions, } \\
\text { can involve } \\
\text { personal opinion } \\
\text { on the topic } \\
\text { based on the } \\
\text { content }\end{array}$ \\
\hline $\begin{array}{l}\text { LOGIC: } \\
\text { Implementing } \\
\text { Concepts and } \\
\text { content }\end{array}$ & $\begin{array}{l}\text { Not implementing } \\
\text { concepts }\end{array}$ & $\begin{array}{l}\text { Low } \\
\text { implementation } \\
\text { or incorrect } \\
\text { application of } \\
\text { concepts }\end{array}$ & $\begin{array}{l}\text { Some application of } \\
\text { concepts, but uses } \\
\text { generic ideas }\end{array}$ & $\begin{array}{l}\text { Total } \\
\text { application of } \\
\text { Concepts and } \\
\text { other contexts } \\
\text { utilizing specific } \\
\text { examples and } \\
\text { information }\end{array}$ \\
\hline
\end{tabular}

\section{Results and Discussion}

The six standards of critical thinking skills in students were examined and assessed by two raters, namely the researcher and another English lecturer. Table 2 indicates the students' scores in each topic using Leist et al. (2012) critical thinking scoring system.

Table 2. The Level of students' critical thinking

\begin{tabular}{lcccc}
\hline No & $\begin{array}{c}\text { TOPIC 1 } \\
\text { Ac, Cl, Pre, Dp, Re, } \\
\text { Lo }\end{array}$ & $\begin{array}{c}\text { TOPIC 2 } \\
\text { Ac, Cl, Pre, Dp, } \\
\text { Re, Lo }\end{array}$ & $\begin{array}{c}\text { TOPIC 3 } \\
\text { Ac, Cl, Pre, Dp, } \\
\text { Re, Lo }\end{array}$ & $\begin{array}{c}\text { TOPIC 3 } \\
\text { Ac, Cl, Pre, Dp, } \\
\text { Re, Lo }\end{array}$ \\
\hline P1 & $3+3+3+3+4+3=\mathbf{1 9}$ & $4+3+3+3+4+3=\mathbf{2 0}$ & $4+4+4+3+4+3=\mathbf{2 2}$ & $4+4+3+4+4+3=\mathbf{2 2}$ \\
\hline P2 & $3+3+3+3+4+3=\mathbf{1 9}$ & $3+3+3+3+4+3=\mathbf{1 9}$ & $4+3+3+3+4+3=\mathbf{2 0}$ & $4+4+4+3+4+3=\mathbf{2 2}$ \\
\hline P3 & $2+2+3+2+2+2=\mathbf{1 4}$ & $3+3+3+3+3+3=\mathbf{1 8}$ & $3+3+3+3+4+3=\mathbf{1 9}$ & $4+3+3+3+3+3=\mathbf{1 9}$ \\
\hline P4 & $2+3+3+2+2+2=\mathbf{1 4}$ & $3+3+2+3+4+3=\mathbf{1 8}$ & $3+3+4+4+3+3=\mathbf{2 0}$ & $4+4+3+3+4+3=\mathbf{2 1}$ \\
\hline P5 & $1+2+2+2+2+1=\mathbf{1 0}$ & $2+2+3+2+2+2=\mathbf{1 3}$ & $2+2+2+3+2+2=\mathbf{1 3}$ & $3+2+2+3+2+2=\mathbf{1 4}$ \\
\hline P6 & $1+2+2+2+2+1=\mathbf{1 1}$ & $2+3+2+2+2+1=\mathbf{1 2}$ & $3+3+2+2+2+1=\mathbf{1 3}$ & $2+3+2+2+2+2=\mathbf{1 3}$ \\
\hline P7 & $2+2+2+2+1+1=\mathbf{1 0}$ & $2+2+2+2+2+1=\mathbf{1 1}$ & $2+3+2+2+2+2=\mathbf{1 3}$ & $3+2+2+2+2+2=\mathbf{1 3}$ \\
\hline \multicolumn{7}{c}{$A c=$ accuracy $\mathrm{Cl}=$ clarity Pre=precision Dp $=$ depth Re= relevance $L o=$ logic }
\end{tabular}

In the second meeting, the lecturer discussed the students' problem when accomplishing the first task. In each reading passage, students were expected to explain six questions. When answering task 1, some students indicated that it was not easy for them to use critical thinking to analyze the texts, while the weak ones had problems in all elements. However, the lecturer found two elements of critical thinking that caused much greater problems than others, namely identifying/generating conclusion as well as expressing a personal opinion 
(SE5), and identifying the writer's purpose (SE1). The following are possible reasons students had problems in these particular areas:

\section{Lack of English mastery (P5, P6, and P7).}

Here is the excerpt of the interview in Indonesian when answering question 5 (S5)

P5: "sebenarnya saya mengerti...tapi...saya kesulitan menulisnya secara mendetail dalam bahasa Inggris...karena saya harus menerangkan dengan lengkap....hal lain kosa kata yang terbatas juga masalah ...jadi saya menulis sebisa saya saja....." Although I understand the topic... I find it difficult to provide a detailed explanation in English due to my limited vocabulary... However, I write as much as I can ......"

Here is the excerpt of student P5 (topic 1) when answering question 5 (S5):

In my opinion, it was all true because many of my friends were like that and after graduating from college, had gotten a permanent job with a high position. if he wants to get out, must adapt again.

However, students with better English did not have problems drawing conclusions and expressing their opinion. Here is the excerpt of student P1 (topic 1) when answering question 5 (S5).

In my personal opinion, I agree that working while attending school is a good idea. It makes students to be more appreciative of everything they have and encourages them to learn how to save money because earning it is not easy. They also learn to respect time, when to work, study, and play to understand that life does not always go according to their wishes. By working, they are also exposed to knowing more people and understand that not everyone has similar characteristics. The greatest lesson students failed to acquire from college was getting used to the difficulties of life out there.

\section{Lack of prior knowledge and practice (P5, P6, and P7)}

The second hardest question is to determine the purpose of the text. Here is the excerpt from the interview in Indonesian.

P5"Sulit untuk saya memahami arti yang tersirat dalam membaca......saya harus menemukan dan memahami arti yang tersirat di dalam teks." It is difficult for me to understand the implied meaning in reading ...... therefore, I tend to make out time to find and understand the meaning in every text......

The act of reading is also associated with some information, which is difficult to determine without knowing the writer's purpose. Therefore, students tend to find it difficult when the text contains implied meaning because they had no knowledge of what the writer means and are not used to practicing critical reading.

According to Heidari (2020), a number of readers read between and beyond the lines of a text. Reading between the lines involves making a relationship between the information explicitly said in various parts of a text and understanding their interrelationship. While reading beyond the lines means the ability to relate the information expressed in the reading passage to background knowledge in order to grasp the understanding and interpretation of the author's envisioned meaning.

Besides a lack of English mastery, students P5, P6, and P7 only read the line where they found explicit information. The finding showed that students that do not have good language mastery and lacked background knowledge found it difficult to establish their critical thinking and comprehension. Although it is important to practice their comprehension skills, however, background knowledge and vocabulary are more important 
as they have to relate them to the topic in order to achieve their comprehension (Sedita, 2018). Therefore, readers with strong background knowledge comprehend better than those with a poor background (Aloqaili, 2012). Meanwhile, average students can improve their critical thinking through sequential reading because they had adequate English language mastery (P3, and P4).

\section{Conclusion}

The findings demonstrated improvement in students' ability to possess critical thinking through critical reading strategies. However, the improvement was not very significant for students with poor English mastery because they lacked critical thinking elements compared to those with good English abilities. Therefore, the use of a five- in teaching critical thinking when reading is worth trying. However, to make this strategy more effective, the participants need to possess adequate English knowledge, while the teacher needs to provide an interesting topic to stimulate their critical thinking. Furthermore, students are inclined to develop their critical thinking when the topics are thoughtprovoking and familiar. The use of critical reading strategies can also expand their interest in reading, thereby making them aware of the importance of literacy

\section{References}

Aloqaili, A. S. (2012). The relationship between reading comprehension and critical thinking: A theoretical study. Journal of King Saud University - Languages and Translation, 24(1), 35-41. https://doi.org/10.1016/j.jksult.2011.01.001

Anderson, L. W., Krathwohl, D. R., \& Bloom, B. S. (2001). A taxonomy for learning, teaching, and assessing: a revision of Bloom's taxonomy of educational objectives. 41(4), $352 . \quad$ Retrieved from http://books.google.com/books?id=JPkXAQAAMAAJ\&pgis=1

Arifin, S., Ilyas, H., \& Sukmawidjaya, M. (2020). Using Journal Entries and Assigned Writing to Promote Students' Critical Thinking. VELES Voices of English Language Education Society, 4(1), 104-115. https://doi.org/10.29408/veles.v4i1.2020

Bloom, B. S. (1956). Taxonomy of Educational Objectives. Volume 1: Cognitive Domain. New York: McKay:1956.

Brown,

D.

(2000).

[H._Douglas_Brown]_Teaching_by_Principles,_Second_(BookFi.org).pdf. Teaching by Principles An Interactive Approach to Language Pedagogy, p. 491. Retrieved from https://octovany.files.wordpress.com/2013/12/ok-teaching-by-principles-hdouglas-brown.pdf

Chou, P. T. M. (2011). The effects of vocabulary knowledge and background knowledge on reading comprehension of Taiwanese EFL students. Electronic Journal of Foreign Language Teaching, 8(1), 108-115. Retrieved from https://www.researchgate.net/publication/285929273_The_effects_of_vocabulary_kn owledge_and_background_knowledge_on_reading_comprehension_of_Taiwanese_E FL_students

Din, M. (2020). Evaluating university students' critical thinking ability as reflected in their critical reading skill: A study at bachelor level in Pakistan. Thinking Skills and Creativity, 35(September 2019), 1-11. https://doi.org/10.1016/j.tsc.2020.100627

Dorkchandra, D. (2013). The Effects of Question Generating Strategy Instruction on EFL Freshmen' s Reading Comprehension and Use of English Tenses. Journal of Liberal 
Arts,

$5(2)$

$32-45$.

Retrieved

from

https://www.researchgate.net/publication/285929273_The_effects_of_vocabulary_kn owledge_and_background_knowledge_on_reading_comprehension_of_Taiwanese_E FL_students

Fadhillah, A. M. (2017). Embedding Critical Thinking Through Critical Reading: Teaching Narrative Text. Journal of English and Education, 5(2), 92-102. Retrieved from https://ejournal.upi.edu/index.php/L-E/article/view/9938

Femilia, P. S. (2018). Critical Reading Strategies Employed By Good Critical Readers of Graduate Students in Elt , State University of Malang. Tefla Journal, 1(1), 30-34. Retrieved from http://repository.um.ac.id/id/eprint/58736

Grabe, W., \& Stoller, F. L. (2013). Teaching and researching reading, second edition. In C. N. C. and D. R. Hall (Ed.), Teaching and Researching Reading, Second Edition (2nd Editio). https://doi.org/10.4324/9781315833743

Griggs, R. A., Jackson, S. L., Marek, P., \& Christopher, A. N. (1998). Critical Thinking in Introductory Psychology Texts and Supplements. Teaching of Psychology, 25(4), 254-266. https://doi.org/10.1080/00986289809709711

Halvorsen, A. (2005). Incorporating Critical Thinking Skills Development into ESL/EFL Courses. The Internet TESL Journal, XI(3), 1-6. Retrieved from http://iteslj.org/Techniques/Halvorsen-CriticalThinking.html

Heidari, K. (2020). Critical thinking and EFL learners' performance on textually-explicit, textually-implicit, and script-based reading items. Thinking Skills and Creativity, 37(August), 100703. https://doi.org/10.1016/j.tsc.2020.100703

Hogsette, D., \& Glazer, F. (2012). Tips From Innovative Teaching at UWF : Develop Critical Thinking Skills through Journal Writing. (7), 7-8. Retrieved from https://www.academia.edu/3708624/Develop_Critical_Thinking_Skills_through_Jour nal_Writing

Ilyas, H. P. (2018). Indonesian EFL Teachers' Conceptions of Critical Thinking Hamzah. Journal of ELT Research, 3(1), 30-37. https://doi.org/10.22236/JER

Kadir, N. A., Subki, R. N., Haneem, F., Jamal, A., \& Ismail, J. (2014). The Importance of Teaching Critical Reading Skills in a Malaysian Reading Classroom. The 2014 WEI International Academic Conference Proceedings, 208-219. Retrieved from https://www.westeastinstitute.com/wp-content/uploads/2014/06/Norbaiyah-AbdKadir-Full-Paper.pdf

Karimi, L., \& Veisi, F. (2016). The Impact of Teaching Critical Thinking Skills on Reading Comprehension of Iranian EFL Learners. Journal of Language Teaching and Research, 6(9), 1869-1876. http://dx.doi.org/10.17507/tpls.0609.21

Kurland, D. (2000). CRITICAL READING AND CRITICAL THINKING. 8(July), 104-108. https://doi.org/10.1016/S1607-551X(08)70131-1

Leist, C. W., Woolwine, Mark ACathy W. Leist, Mark A. Woolwine, C. L. B., \& Bays, C. L. (2012). The Effects of Using a Critical Thinking Scoring Rubric to Assess Undergraduate Students' Reading Skills. Journal of College Reading and Learning, 43(1), 31-58. https://doi.org/10.1080/10790195.2012.10850361

McDonald, L. (2004). Moving from reader response to critical reading: developing 10-11year-olds' ability as analytical readers of literary texts. Literacy (Formerly Reading), 38(1), 17-25. https://doi.org/10.1111/j.0034-0472.2004.03801004.x

Moore, T. (2013). Critical thinking: Seven definitions in search of a concept. Studies in 
Higher Education, 38(4), 506-522. https://doi.org/10.1080/03075079.2011.586995

Pardede, P. (2007). Developing Critical Reading in EFL Classroom 1. Conference Paper, (December).

Paul, R., \& Elder, L. (2007a). Critical Thinking Competency Standards. In Foundation for Critical Thinking Press. Retrieved https://curriculum.gov.bc.ca/sites/curriculum.gov.bc.ca/files/pdf/CriticalThinkingCo mpetencyProfiles.pdf

Paul, R., \& Elder, L. (2007b). Critical Thinking Concepts and Tools.pdf. 27th International Conference on Critical Thinking, pp. 1-21. Retrieved from http://web.iitd.ac.in/ nkurur/2015-16/IIsem/cml522/CriticalThinking.pdf

Reed, J. H. (1998). Effect of a model for critical thinking on student achievement in primary source document analysis and interpretation, argumentative reasoning, critical thinking dispositions, and history content in a community college history course (UNIVERSITY OF SOUTH FLORIDA). Retrieved from https://search.proquest.com/docview/304454601?accountid=10673\%0Ahttp://openurl .ac.uk/redirect/athens:edu/?url_ver=Z39.88-

2004\&rft_val_fmt=info:ofi/fmt:kev:mtx:dissertation \&genre=dissertations $+\&+$ theses \&sid=ProQ:ProQuest+Dissertations $+\&+$ Theses+Global\&atit

Sedita, J. (2018). Background Knowledge and Reading Comprehension - Keys to Literacy. Retrieved October 4, 2020, from https://keystoliteracy.com/blog/backgroundknowledge-and-reading-comprehension/

Shaarawy, H. Y. (2014). The Effect of Journal Writing on Students' Cognitive Critical Thinking Skills A Quasi-Experiment Research on an EFL Undergraduate Classroom in Egypt. International Journal of Higher Education, 3(4), 120-128. https://doi.org/10.5430/ijhe.v3n4p120

Sinaga, P., \& Feranie, S. (2017). Enhancing critical thinking skills and writing skills through the variation in non-traditional writing task. International Journal of Instruction, 10(2), 69-84. https://doi.org/10.12973/iji.2017.1025a

Stanton, A. D., \& Stanton, W. W. (2017). Using journaling to enhance learning and critical thinking in a retailing course. Journal for Advancement of Marketing Education.

Threlfall, S. J. (2014). E-journals: towards critical and independent reflective practice for students in higher education. Reflective Practice, 15(3), 317-332. https://doi.org/10.1080/14623943.2014.900012

Velayati, N., Muslem, A., Fitriani, S. S., \& Samad, I. A. (2017). An Exploration of Students' Difficulties in Using Critical Thinking Skills in Reading. Al-Ta Lim Journal, 24(3), 195. https://doi.org/10.15548/jt.v24i3.298

Wijayanti, S. (2020). Indonesian Students' Reading Literacy. 390(Icracos 2019), 61-65. https://doi.org/10.2991/icracos-19.2020.13

$\mathrm{Xu}$, J. (2011). The application of critical thinking in teaching english reading. Theory and Practice in Language Studies, 1(2), 136-141. https://doi.org/10.4304/tpls.1.2.136-141 